\title{
Brazilian Universities Incubators: A Panorama from Activities and GDP Perspective
}

\author{
Gustavo da Cruz ${ }^{1}$, Nathália Vieira dos Santos Bezerra ${ }^{1} \&$ João Vitor da Conceição Mendes ${ }^{1}$ \\ ${ }^{1}$ Santa Cruz State University, Ilhéus, Bahia, Brazil \\ Correspondence: Gustavo da Cruz, Department of Management, Santa Cruz State University, Rodovia Ilhéus \\ Itabuna Km 16, Ilhéus, Bahia, Brazil. 45653-200. E-mail: dacruz7777@gmail.com
}

Received: December 30, 2016

Accepted: January 20, 2017

Online Published: January 26, 2017

doi:10.5539/ijbm.v12n2p111

URL: http://dx.doi.org/10.5539/ijbm.v12n2p111

\begin{abstract}
The entrepreneurship can collaborate to the economy and solve environmental problems by contributing to achieve the university third mission through the incubators process as the majority of technology transfer mechanisms. However, Brazilian universities incubators are less developed than the ones from United States and Europe. Therefore, this paper aims to explore Brazilian universities incubators from an activities and Gross Domestic Product (GDP) perspective. As a result, we identified 122 incubators that are from public universities, in their majority and work mainly in social entrepreneurship and base-technology sectors. Universities installed in cities with a high GDP have a restricted number of activities compared to other economic classes, as well as in lower class there are an interesting number of incubators focused on promoting and creating jobs and income generation, corroborating the role of the universities third mission. Incubators are still in consolidation in Brazil, which reflects the early stage of innovation in universities and industries. Recent studies are recommended in the area of incubator management and effectiveness of technology transfer.
\end{abstract}

Keywords: incubators, technology transfer, Brazilian universities, activities, GDP local

\section{Introduction}

In the mid-20, Joseph Schumpeter pointed that innovation plays a fundamental role in economy development. The innovation is described as the search, discovery, experimentation, development and adoption of new products, new methods or new services (Dosi \& Orsenigo, 1988; Roach et al., 2016). This phenomenon allows industries to compete effectively in the increasingly global environment (Warren et al., 2010).

Nevertheless, innovation's concept needs to be understood beyond the high-tech scenario, as it is usually known. In a holistic point of view, Fagerberg et al (2010) argue that the innovation must be understood as an attempt to try new or improved products, processes or ways of doing things that has directs effects into the performance of any organization. Though Schumpeter's thesis has almost 100 years, innovations still have an important role in the economy development of numerous countries (Bukala, 2008) and it has become a powerful element to solve different issues in society (Fagerberg, 2006).

Since economic development and global competition are matters of national interest, universities are increasingly expect to have a direct contribution to the well-being of society and national and regional development (Lee, 1998; Mello \& Etzkowitz, 2008; Piirainen et al., 2016). This new arrangement happened because knowledge became the most significant source of competitive advantage (Pausits, 2015). According to Bekker and Bodas-Freitas (2008), it seems to exist an agreement on the positive impact of academic research on the development of industrial innovation.

Ranga and Etzkowitz (2013) argue that universities are no longer just a traditional source of human resources and knowledge, but also main players into the innovation process. In fact, Shane and Venkataraman (2000) believe that there is a strong synonymous between knowledge, innovation and entrepreneurship. Current researches (Phan \& Siegel, 2006, Clarysse et al., 2011; Perkmann et al., 2015) has shown that entrepreneurship and technological transfer from universities can generate innumerous benefits to society by promoting competitive advance in industries and consequently improving economic development.

As a result, governments around the world are trying to create more academic entrepreneurship through the development of strategic plans, policies and financing mechanism to encourage and set up incubators next to the 
university to associate talent, technology and know-how with the aim of accelerating technology commercialization processes (Clarysse \& Bruneel, 2007; Kirby et al., 2011).

Etzkowitz (2003) and Guerrero-Cano et al. (2006) argue that most of universities becomes a natural incubator that provides support structures for teachers, students and outside partners to initiate new ventures, as intellectual, commercial and conjoint. Universities incubators have the ability to innovate, recognize and create opportunities, take risks and respond to challenges to reach a more promising position in the future (Becker and Gassmann, 2006). However, they are influenced by many external factors, such as nature of an organization, number of organizations in a region, regional culture and economic environment (Clarysse et al., 2005; Stam \& Bosma, 2015; Pauwels et al., 2016).

Despite the growing interest among academics and policy makers worldwide, there are a number of gaps in the understanding of the universities incubators related to the local economic development (Mian, 1997; Grimaldi \& Grandi, 2005; Etzkowitz, 2003; Clarysse et al., 2005; Becker \& Gassmann, 2006; Barbero et al., 2013). In this context, the purpose of this paper is to explore the Brazilian universities incubators from an activities and Gross Domestic Product (GDP) perspective, related to the city in which the university is located. The main argument is that some universities are located in a healthy economic environment, with a high level GDP. These universities have a set of incubators established a long time ago in differents activities, rather than other universities in areas, which presents a low GDP level.

Definitely, there are limited researches analyzing the existence of universities that increase regional competitiveness to stimulate entrepreneurial activities and regional innovation systems (Clarysse \& Moray, 2004; Acs \& Audretsch, 2005; Power \& Malmberg, 2008; Audretsch et al., 2012; Kirby et al., 2011; Baltzopoulos \& Broström, 2013; Stam \& Bosma, 2015). It is important to elucidate that Universities Incubators are more developed in the United States and Europe than in Brazil. The Brazilian incubator movement represents a new direction in Latin American science, technology and industrial policies (Mello \&d Etzkowitz, 2008).

The paper is organized in the following way: Section 2 presents a discussion of the literature review, which is at the intersection of the university's third mission and entrepreneurship. Furthermore, the section refers to technology transfer and incubators. Section 3 focuses on the research method and the main findings of the analysis. Section 4 offers a detailed discussion of the findings, concludes with the limitations of the research and gives directions for further researches.

\section{Literature reviews}

\subsection{Third Mission}

Since 1088, when the first university was established at Bologna (Italy), this long-standing organizations have been able to survive and modificate themselves, incorporating new characteristics and particularities (Antonelli, 2008). In fact, only in 19th century it happened the first academic revolution, when research activities started to be additional to the task of teaching (Etzkowitz, 1998; Etzkowitz \& Leydesdorff, 1999; 2000).

Teaching and research became the two traditional missions until mid-70s, when it started a set of political reforms in US and EU countries, that were headed to improve the transfer of academic research results to industries and governments (Baldini et al., 2006, Guerrero-Cano et al., 2006). The second and continuous academic revolution is characterized for incorporating economic and social development as a new mission from the university (Etzkowitz \& Leydesdorff, 1999; 2000).

Although it is very slow, this continuous academic revolution is based on the university entrepreneurship and technological transfer as the main forces in the innovation process focused on contributing to economic development (Geuna \& Muscio, 2009; Audretsch et al., 2014), in which it must be associated with educational and research activities (Charles et al., 2014). Borrell-Damian (2010) and Trencher et al. (2013) emphasizes the importance of universities to work these missions in a unified project, as a solid combination of education, research and innovation in an endless interaction with industries and governments. The third mission is related to all activities concerning creation, use, application and exploitation of knowledge capabilities outside academic environment (Molas-Gallart \& Castro-Martínez, 2008).

In addition, Trencher et al (2013) considers as a role of the university to collaborate with several social actors to create transformations with the aim of materializing sustainable development in a specific place, region or societal subsector. According to Etzkowitz (1998), the heart of this new mission is the "capitalization of knowledge", in which it is important to establish the university as a significant actor in their own economic environment. As much knowledge is being developed in universities and in government research establishments, they are seen as important catalysts for regional economic and social development, through the spin-off of new and innovative 
enterprises that add value by creating knowledge (Guerrero-Cano et al., 2006). Thorn and Soo (2006) believes that the universities need to create entrepreneurship to expand these social contributions and economic development. Bodas-Freitas et al. (2011) and Ranga et al. (2016), point that the entrepreneurship and knowledge became an important component to the economic development in general, and specially to innovation industry.

In this context, over the last 20 years the US and EU governments have developed a set of policies to motivate universities to increase their technology transfer to the society (Crespi et al., 2007). Taheri and Van Geenhuizen (2016) mentioned that universities are not only seen as educational organizations and creators of new knowledge, but they are also involved in a large set of activities of knowledge commercialization and they are able to produce, according to Phan and Siegel (2006) and Perkmann et al. (2015), many benefits to society by consolidating industries competitive advantage.

Recent researches (Wright et al., 2004; York \& Venkataraman, 2010; Baltzopoulos \& Brostrom, 2013; Stam \& Bosma, 2015) have shown that the entrepreneurship can contribute to economy and solve environmental problems by contributing to achieve the university third mission.

\subsection{Entrepreneurship}

Since entrepreneurship has become an important activity for economic development in several countries (Busenitz et al., 2003), universities turned out to be the main player into this process as an organization where many policies and programs are positioned to ensure that created knowledge and new scientific results help to produce business opportunities (Kirby et al., 2011; Stam \& Bosma, 2015) and develop the university third mission, at the same time (Guerrero-Cano et al., 2006).

Entrepreneurial activities in the universities are not totally new phenomena (Clarysse et al., 2011). In fact, the early active occurred in 17th century in German pharmaceutical science. However, during the past two decades, an increasing number of academic scientists began to write business plans, raise funds to rent locations and recruit people to spillover their ideas and research results (Etzkowitz, 1998).

Entrepreneurship can be conceptualized as a process of creating new opportunities and possibilities by discover, evaluate and exploit development of future products and services (Shane \& Venkataraman, 2000; Guerrero-Cano et al., 2006; Stam et al., 2012). In addition, McMullen and Shepherd (2006) suggest that there is a possibility to access a new market by creating new ventures.

Acs and Ausbertch (2005) describes the field of entrepreneurship as a study of how, by whom and with what consequences the opportunities to produce future goods and services are discovered, evaluated and exploited. Etzkowitz (1998) believes that the full integration of research and entrepreneurship occurs wherever scientists found their own company to continue pursuing a particular sort of research from basic issues to concrete products ready for the market.

According to Shane and Venkataraman (2000) and Guerrero-Cano et al. (2006), entrepreneurship involves joint production, in which several different resources have to be brought together to create a new product or service, and it does not require, but can include the creation of new organizations. Sporn (2001) add that the entrepreneurship is characterized by an environment of innovation, challenges, responsibilities, changes and rewards that helps the university missions. Furthermore, Kirby et al. (2011) point out that the entrepreneurial culture includes, but it is not limited to: values, rules and attitudes.

University is usually associated with productivity gains and innovation in existing industries, although Baltzouplos and Brostrom (2013) point that, the entrepreneurship process among academic activities has a significant influence into the formation and location of new industries that offer a product or service not previously available. Today, universities have developed a strong competition to maximize the number of growth-oriented spin-offs (Clarysse and Moray, 2004).

In this context, there is growing international attention to the importance of academic entrepreneurship via technology transfer mechanisms (Siegel et al., 2007). Because the establishment of spin-offs activities create additional ways of knowledge dissemination through the university technology (Etzkowitz, 2003).

\subsection{Technology Transfer}

Several studies (Markmann et al., 2005; Phan \& Siegel, 2006; Link et al., 2007; Geuna \& Muscio, 2009; Mowery \& Ziedonis, 2014; Anatan, 2015; Gervais et al., 2016) consider the technology transfer with a many-sided nature. According to Gilsing et al. (2011), it has been demonstrated how a wide range of factors affects the transfer of technological knowledge from universities to industry.

The third mission requires that universities improve their capacity to generate and transfer new technologies based 
on knowledge and skills these organizations have (Ranga \& Etzkowitz (2013) to become, consequently, the main innovation suppliers (Siegel et al., 2007; Borrell-Damian, 2010).

Schaeffer et al. (2015) believe that because of the importance of knowledge in society today, it was possible to create a new connection between science and technology in which the interaction between academic research and industrial innovation is highlighted. In addition, Bukala (2008) points that this interaction between two or more organizations during a knowledge or technical producing process is the main goal of technology transfer.

Therefore, technology transfer can be defined by the movement of technology by the use of some communication channels from one place to another, for example, from a university to an organization, or from a country to another (Zhao and Reism 1992; Rogers et al., 2001; Guan et al., 2006). In fact, this movement involves any kind of activities and processes through incorporated products, processes or knowledge passed from one user to another (Bessant \& Rush, 1993).

Based on the literature studies (Reddy \& Zhao, 1990; Etzkowitz \& Leydesdorff, 1998; 1999; Chapple et al., 2005; Phan \& Siegel, 2006; Ranga \& Etzkowitz, 2013; Audretsch et al., 2014; Anatan, 2015), it is evident that technology transfer has a wide conceptualization because it also refers to: use, mobilization, application, exchange, development and management related to product, service, technology and knowledge.

Bozeman (2000) argue the definition of technology transfer sometimes create conflicting due of different refers involve. However, one thing is certain: it will be success when the technology is introduced into the market with a purpose for further use and commercialization (AUTM, 2002; Geuna \& Muscio, 2009). In fact, analyze and understand the technology transfer from universities into marketable ideas became one of the most important topics in academic research (Audretsch et al., 2014). The creation of an infrastructure at universities is significant not only for an inclusion of a marketing support, but also for its ability to enhance the commercialization of academic knowledge (Etzkowitz, 2003).

There are a several formal technology transfer mechanisms, which include, but it is not limited to: collaborative research, research joint ventures, technology consulting, strategic alliances, licensing and acquisition, spin-off companies and incubators (Link et al., 2007, Markmann et al., 2005; Muscio et al., 2014; Ranga et al., 2016).

Geuna and Muscio (2009) point that universities are trying to promote the technology transfer with new mechanisms with the purpose of being succeeful in the third mission activities, related to new ventures or income from entrepreneurial activities such as the incubation of new ventures driven to society. Becker and Gassmann (2006) and Bruneel et al. (2012) believe that university incubators are a potential vehicle with which the commercialization of research can be supported and they are also a popular tool to accelerate the development of successful entrepreneurial companies.

\subsection{Incubators}

The first incubator emerged in the mid-50s at the Stanford Research Park - USA in which aimed to converge the interests of research center of university, government agencies and entrepreneurs to regional economic and technological development (Fonseca, 2014). Only in the early 1980s, there was a growth of universities interested in setting up incubators in/or around university campuses to support their traditional mission of teaching, research and public service and to include in their region's economic development a more dynamic participation (Mian, 1997; Becker \& Gassmann, 2006).

According to Bruneel et al. (2012), incubators are popular tools to accelerate the creation of successful entrepreneurial companies. As in previous work carried out by Phan et al. (2005) indicate more than 900 incubators in the European Union and over 1.400 in the US. Numbers show a noticeable increase in recent decades. As a result, Clarysse et al. (2007) there is a convergence in the acknowledgement of the importance of incubators institutional establishment as a part of an innovation system.

Some studies (Mian, 1997; Clarysse et al., 2005; Bergek \& Norrman, 2008; Barbero et al., 2013, Soetanto \& Jack, 2013) describes similar definitions of incubators, as organizations dedicated to supporting emerging businesses and focus on business development. In additional, the incubation seeks to connect technology, financial resources and know-how in order to explore the entrepreneurial talent, accelerate the development of new companies and the commercialization of new technologies (Mian, 1997; Grimaldi \& Grandi, 2005). Furthermore, Becker and Gassmann (2006) believe that incubators can strengthen the tie between basic research and science and development.

According to UKBI (2007), incubation is a unique and highly flexible combination of business development processes, infrastructure and people, designed to nurture and grow new and small businesses by supporting them through the early stages of development and change. For this reason, a university incubator has a high number of 
young enterprises with growth potential, an established entrepreneurial culture, strong links with industry and a structure which facilitates access to financial markets (Aernoudt, 2004).

In addition, Phan et al. (2005) point out four main components of an incubator: physical office space, shared resources, professional support and access to a business network. According to Etzkowitz (2003), an incubator must be considered an example of location that generates business innovation practices.

Bruneel et al. (2012) point that the incubators typically support new ventures expecting to develop into self-sustaining, in other words, thriving companies providing their tenants with a mix of services surrounding infrastructure, business support services and networking

Bergek and Norrman (2008) argue that there are two main purposes for an incubator: one is to strengthen economic development and reduce unemployment in a particular region, by creating new businesses. The other purpose is to encourage companies involved in emerging technologies researches or transfer started in universities, research institutes and other companies. Apart of it, the main goal is to create successful that will leave the stage of an incubator to be financially viable and freestanding within a reasonable time (Aernoudt, 2004).

Becker and Gassmann (2006) indicate that university incubators are usually non-profit incubators that feed a social purpose with public funded money. For-profit incubators, such as corporate incubators, stress financial returns. This situation might change in the future, with the increase of established private and corporate universities. The increased private funding of university research may furthermore allow even public universities to establish private incubators.

For-profit incubators are professionally organized and achieve profits from the participation in new ventures. This type of organization is able to access a pool of internal knowledge such as technology, suppliers, customers and business development, management expertise and assets such as finance (Barbero et al., 2013).

Unfortunately, it is very difficult to establish an appropriate measure to incubators performance, because understanding the phenomenon remains restricted (Clarysse et al., 2005). Nevertheless, a previous work carried out by Bruneel et al. (2012) shows that incubators have an important contribution to university-industry interaction, innovation activity and company's performance.

\section{Methodology}

The research design employed an inductive approach in order to obtain a rich understanding on the Brazilian universities incubators from a Gross Domestic Product (GDP) perspective. For the definition of the sample, it was picked up the ranking prepared by Folha (2016), which listed the 100 most highly evaluated universities in Brazil through criteria such as teaching, market, internationalization, research and innovation. It is important to emphasize that this sample is made up of small, medium and large universities, with public and private purposes, located in several Brazilian states, giving this sample a very heterogeneous character.

Due to the amplitude of the sample, the quantitative method of data collection was chosen, in which the following variables were addressed: year of inauguration and incubator area, city and GDP of the locality where the incubator is installed and university's typology as to its economic purpose. Such data were obtained from secondary sources such as websites and annual reports from universities and/or incubators collected in August and September 2016, and GDP data were obtained from the IBGE statistical reports (2013).

With the purpose of a better data cross-referencing, the GDP values for the cities where the incubators are located, were grouped into 5 classes according to the IBGE guidelines (2013) presented in Table 1. After data tabulation, it was possible to analyze the Brazilian incubators scenario, comparing them from a perspective by activities and local economy.

Table 2. GDP class

\begin{tabular}{lll}
\hline GDP by thousand - Euro & & Class \\
\hline 22.800 .000 & $>$ & $\mathrm{A}$ \\
2.800 .000 & 22.800 .000 & $\mathrm{~B}$ \\
1.400 .000 & 2.800 .000 & $\mathrm{C}$ \\
280.000 & 1.400 .000 & $\mathrm{D}$ \\
140.000 & 280.000 & $\mathrm{E}$ \\
70.000 & 140.000 & $\mathrm{~F}$ \\
14.000 & 70.000 & $\mathrm{G}$ \\
$<$ & 14.000 & $\mathrm{H}$ \\
\hline
\end{tabular}




\section{Results}

It was verified that of the first 100 Brazilian universities listed in Folha ranking (2016), 18\% do not have incubators in their campuses, all of them being private institutions. This fact is possibly due to the fact that these universities are small and prioritize teaching activities over the research. It is worth noting that $84 \%$ of these universities are located in cities with a high economic development (28\% in class A GDP and 56\% in class B), such as São Paulo, Rio de Janeiro and Brasília. Of the $85 \%$ universities that have incubators in their campuses, a total of 122 incubators were identified, as some universities have more than one incubator in their facilities. Of the universities that have incubators, $82 \%$ are located in public institutions located in the great majority in the Southwest region of Brazil, representing 35\%. The south and northeast regions correspond to $29 \%$ and $25 \%$ respectively, the north and center-west regions have only $5 \%$ and $6 \%$ of the Brazilian incubators as represented in Figure 1.

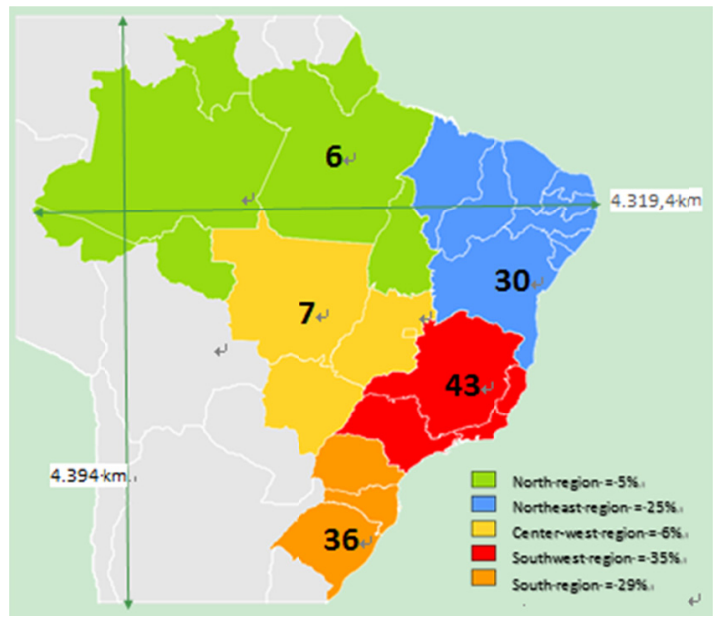

Figure 1. Absolute number and percentage of incubators installed by region of Brazil

Source: Own elaboration.

Regarding to incubators' year of inauguration, it was identified that the period in which more incubators were installed in Brazil was between 2007 and 2011, representing almost 25\% as shown in Table 3. It is also verified that the incubation activities in Brazil are quite recent. Before 1994, there were only two incubators installed in the country. It is possible to relate that the implantation in the last years of motivational public policies to innovation and entrepreneurship encouraged universities to develop activities of teaching and research in these areas.

It is verified that activities of technological base and social entrepreneurship represent, respectively, $25.4 \%$ and $24.6 \%$ of incubators in Brazil. There are also some incubators that have two main activities, such as Agronomy and Biotechnology (1.6\%) as well as Social Entrepreneurship and Technology Base (1.6\%). Nevertheless, 22.1\% of the incubators are characterized by being active in multiple sectors, that is, the same incubator develops activities in the engineering, biotechnology, agronomy and social entrepreneurship activity, for example.

It can be seen in Table 2 that the number of opening incubators in the social entrepreneurship activity is almost linear in the last 15 years. This shows that even though there is an agreement about the importance of innovation for the competitiveness of companies and the availability of technological resources of high performance in universities, many activities are focused on reducing the economic inequality that exists in Brazil. This fact reinforces the third mission of the university, that is, to be a regional economic development agenda as initially addressed in this article.

An interesting fact is that although Brazil has the greatest biological diversity in the world (Bolzani, 2016) and also undergraduate and postgraduate biology programs in almost all Brazilian universities, there are very few incubators that work in the Biotechnology area. It is believed that this number should increase considerably in the coming years due to the publication of Law No. 13.123 (2015), which regulates access to biodiversity and technology transfer between the parts in Brazil, based on the Convention on Biological Diversity. This document is recognized as the main instrument at international level in order to establish legal standards for the promotion 
of economic activities related to environment and development.

It is believed that $7.4 \%$ of incubators that qualify themselves as innovators do not yet have a clear role for their activities. The main scope of any incubator is innovation, it is to undertake new products and business, that is, innovation is inherent in the incubation process as initially addressed in this article. This situation may change over the next few years as these incubators consolidate their true scopes.

It can be seen in Table 3 that there are only a few (12.4\%) incubators in universities located in cities that have a high level of GDP, Class A, as well as they have a smaller variety of activities, since most of them work with Multi-Sectors and Social Entrepreneurship. Unlike the other Class of GDP, Class A has a very limited number of base-technology incubators and none in the engineering and biotechnology, although they are activities with great potential for innovation because they are located in cities with high economic development. Nevertheless, $50 \%$ of the incubators are located in universities whose GDP of respective cities are Class B, reflecting the economic condition of the country in which most of the universities are located in big urban centers. It is also noticed that Class B has a great variety of activities of performance. Base-technology and social entrepreneurship incubators are the ones with greater volume, with emphasis also for Agronomy and Biotechnology.

Considering that cities with a medium level of GDP, Class C, own 15.5\% of the incubators in Brazil, most of them have Social Entrepreneurship activities. Agronomy and biotechnology have a very restricted number of incubators. It is verified that $21 \%$ of the incubators are in universities whose cities GDP are of Class D, low average level, in which this fact becomes interesting since they are cities less favored economically but they possess a significant number of base technology and social entrepreneurship incubators. This situation is probably due to the fact that universities need to stimulate the creation of new jobs and income since economic activity is very limited in these regions, corroborating in this way with the role of universities third mission.

In Class E, whose GDP is low, there is only one university that has an incubator in the technology-based activity. This is due to the fact that in cities of low economic development, the number of universities and incubators is still quite restricted in Brazil, even with the implementation of public policies in recent years for the creation of new universities in economically less favored regions. It is also noticed that Social Entrepreneurship incubators are present at almost all GDP levels, with the base-technology activity concentrating mainly at the medium/high level. Incubation activities such as agronomy, engineering and biotechnology are still quite restricted in Brazil, especially in universities located in medium/low GDP cities.

Table 2. Year of incubators' inauguration by activities

\begin{tabular}{|c|c|c|c|c|c|c|c|c|c|c|c|c|}
\hline & Agronomy & $\begin{array}{l}\text { Agronomy } \\
\text { and } \\
\text { Biotechnology }\end{array}$ & Biotechnology & Engineering & Innovation & Multi-sector & $\begin{array}{l}\text { Social } \\
\text { entrepreneurship }\end{array}$ & $\begin{array}{l}\text { Social } \\
\text { entrepreneurship } \\
\text { and Tech-base }\end{array}$ & Tech-base & Others & Total & \\
\hline$\%$ & $4,1 \%$ & $1,6 \%$ & $3,3 \%$ & $1,6 \%$ & $7,4 \%$ & $22,1 \%$ & $24,6 \%$ & $1,6 \%$ & $25,4 \%$ & $8,2 \%$ & $100 \%$ & \\
\hline Quant. & 5 & 2 & 4 & 2 & 9 & 27 & 30 & 2 & 31 & 10 & 122 & \\
\hline YEARS & & & & & & & & & & & Quant. & $\%$ \\
\hline 1986 & & & & & & & & & 1 & & 1 & \\
\hline 1990 & & & & & 1 & & & & & & 1 & \\
\hline 1994 & & & & & & 2 & 1 & & & 1 & 4 & $10,6 \%$ \\
\hline 1995 & & & & & & 1 & 1 & & 2 & & 4 & \\
\hline 1996 & & & & & & 1 & & & 2 & & 3 & \\
\hline 1997 & & & & & 1 & 1 & & & & & 2 & \\
\hline 1998 & & & & & & 1 & 1 & 1 & & & 3 & \\
\hline 1999 & 1 & & & & 1 & 1 & 2 & & 1 & & 6 & $20,5 \%$ \\
\hline 2000 & 1 & & & & & 2 & 2 & & 2 & 1 & 8 & \\
\hline 2001 & 1 & 1 & 1 & & & 1 & 1 & 1 & & & 6 & \\
\hline 2002 & & & & & & 1 & & & & & 1 & \\
\hline 2003 & & & & & 1 & 2 & 1 & & 2 & 2 & 8 & \\
\hline 2004 & & 1 & & 1 & & 2 & & & 1 & & 5 & $22,2 \%$ \\
\hline 2005 & 1 & & & & & 2 & 3 & & 4 & & 10 & \\
\hline 2006 & & & & & & & 2 & & 1 & & 3 & \\
\hline 2007 & & & & & & 1 & 3 & & & 1 & 5 & $245 \%$ \\
\hline 2008 & & & & & 1 & 3 & 2 & & & 2 & 8 & $24,5 \%$ \\
\hline
\end{tabular}




\begin{tabular}{|c|c|c|c|c|c|c|c|c|c|c|}
\hline 2009 & & & 1 & 2 & 2 & & 3 & & 8 & \\
\hline 2010 & & 1 & & & 1 & 1 & & 2 & 5 & \\
\hline 2011 & & & & & & 3 & 1 & & 4 & \\
\hline 2013 & & & & & & & & 1 & 1 & \\
\hline 2014 & & 1 & & & & 3 & 4 & & 8 & $22,2 \%$ \\
\hline 2015 & & 1 & & 1 & 1 & 1 & 2 & & 6 & \\
\hline 2016 & 1 & & & 1 & & & 2 & & 4 & \\
\hline
\end{tabular}

Table 3. Incubators distribution by area of operation

\begin{tabular}{|c|c|c|c|c|c|}
\hline INCUBATION ACTIVITIES & $\begin{array}{l}\text { GDP class } \\
\text { A }\end{array}$ & GDP class B & $\begin{array}{l}\text { GDP } \\
\text { Class C }\end{array}$ & $\begin{array}{ll}\text { GDP class } \\
\text { D }\end{array}$ & GDP class $\mathbf{E}$ \\
\hline Agronomy & - & 3 & 1 & 1 & - \\
\hline Agronomy and Biotechnology & - & 2 & - & 1 & - \\
\hline Biotechnology & - & 2 & 1 & 1 & - \\
\hline Engineering & - & 2 & - & - & - \\
\hline Innovation & 3 & 5 & 1 & - & - \\
\hline Multi-sector & 4 & 12 & 4 & 7 & - \\
\hline Social entrepreneurship & 3 & 14 & 7 & 6 & - \\
\hline Social entrepreneurship and Tech-base & 1 & - & - & - & - \\
\hline Tech-base & 1 & 17 & 5 & 7 & 1 \\
\hline Others & 3 & 4 & - & 3 & - \\
\hline Total Absolut per class & 15 & 61 & 19 & 26 & 1 \\
\hline Total Percentual per class & $12,4 \%$ & $50 \%$ & $15,5 \%$ & $21,3 \%$ & $0,8 \%$ \\
\hline
\end{tabular}

\section{Conclusion}

It is well known that incubators play an important role in innovation and consequently in economic development, but research on their activities, management and effectiveness is still very restricted. The gap in the literature we address is the need to understand the types of incubators, their areas of activity and their place in the different economic classes of Brazilian cities. The results suit to understand the adoption of public policies to encourage innovation, construction of future relationships between universities and industries, as well as incubators managers with the aim of improving the efficiency of their entrepreneurship incubation and entrepreneurship initiatives in Brazil.

It is important to note that according to the Global Competitiveness Report 2015-2016, prepared by The World Economic Forum (WEF, 2016), Brazil is in a transition from level 2 - Driver of Efficiency to level 3 - Driver of Innovation. Regarding to indicators for innovation in Brazil, it has a 3.8 index for Universities-Industry collaboration and 3.1 for research and development (R\&D). Comparing to countries like Switzerland whose same indicators present 6.0 and 5.8 respectively, it is clear that although Brazil and its universities are on the right track, there is still a long way of investments and joint actions that increasingly incorporate the third mission of the universities, thus reflecting national economy and productivity.

\section{Reference}

Acs, Z. J., \& Audretsch, D. B. (2005). Entrepreneurship, Innovation and Technological Change. Foundations and Trends in Entrepreneurship, 1(4), 149-195. https://doi.org/10.1561/0300000004

Aernoudt, R. (2004). Incubators: Tool for entrepreneurship. Small business economics, 23, 127-135. https://doi.org/10.1023/B:SBEJ.0000027665.54173.23

Anatan, L. (2015). Conceptual Issues in University to Industry Knowledge Transfer Studies: A Literature Review. Procedia-Social and Behavioral Sciences, 211, 711-717. https://doi.org/10.1016/j.sbspro.2015.11.090

Antonelli, C. (2008). The new economics of the university: A knowledge governance approach. The Journal of Technology Transfer, 33(1), 1-22. https://doi.org/10.1007/s10961-007-9064-9

Association of University Technology Managers. (2002). The AUTM Licensing Survey: Fiscal Year 2000. Association of University Technology Managers, Norwalk, CT.

Audretsch, D. B., Hulsbeck, M., \& Lehmann, E. E. (2012). Regional competitiveness, university spillovers, and 
entrepreneurial activity. Small Bus Econ, 39, 587-601. https://doi.org/10.1007/s11187-011-9332-9

Audretsch, D. B., Lehmann, E. E., \& Wright, M. (2014). Technology transfer in a global economy. Journal Technol Transfer, 39, 301-312. https://doi.org/10.1007/s10961-012-9283-6

Baldini, N., Grimaldi, R., \& Sobrero, M. (2006). Institutional changes and the commercialization of academic knowledge: A study of Italian universities' patenting activities between 1965 and 2002. Research policy, 35(4), 518-532. https://doi.org/10.1016/j.respol.2006.01.004

Baltzopoulos, A., \& Brostrom, A. (2013). Attractors of Entrepreneurial Activity: Universities, Regions and Alumni Entrepreneurs. Regional Studies, 47(6), 934-949. https://doi.org/10.1080/00343404.2011.602335

Barbero, L. J., Casillas, C. J., Wright, M., \& Garcia, R. A. (2013). Do different types of incubators produce different types of innovations? Springer Science+Business Media New York.

Becker, B., \& Gassamann, O. (2006). Corporate Incubators: Industrial R\&D and What Universities Can Learn from Them. Journal of Technology Transfer, 31, 469-483. https://doi.org/10.1007/s10961-006-0008-6

Bekkers, R., \& Bodas-Freitas, I. M. (2008). Analysing knowledge transfer channels between universities and industry: To what degree do sectors also matter? Research Policy, 37, 1837-1853. https://doi.org/10.1016/j.respol.2008.07.007

Bergek, A., \& Norrman, C. (2008). Incubator best practice: A framework. Technovation, 28, 20-28. https://doi.org/10.1016/j.technovation.2007.07.008

Bessant, J., \& Rush, H. (1993). Government support of manufacturing innovation: two country level case study. IEEE Transactions of Engineering Management, 40(1), 79-91. https://doi.org/10.1109/17.206655

Bodas-Freitas, I. M., Geuna, A., \& Rossi, F. (2011). Patterns of Collaborations between Regional Firms and Universities: Evidence from the Piedmont region in Italy. Collaborations? LEI \& BRICK Working Paper 05/2011, Department of Economics, University of Torino, pp 1-33.

Borrell-Damian, L. (2010). Collaborative Doctoral education: University-industry partnerships for enhancing knowledge exchange. DOC-CAREERS Project. Brussels: European University Association.

Bozeman, B. (2000). Technology transfer and public policy: A review of research and Theory. Research Policy, 29, 627-655. https://doi.org/10.1016/S0048-7333(99)00093-1

Bruneel, J., Ratinho, T., Clarysse, B., \& Groen, A. (2012). The Evolution of Business Incubators: Comparing demand and supply of business incubation services across different incubator generations. Technovation, 32, 110-121. https://doi.org/10.1016/j.technovation.2011.11.003

Bukala, A. (2008). What innovation and technology transfer really mean? Journal of Automation, Mobile Robotics \& Intelligent Systems, 2(2), 70-72.

Busenitz, L. W., West III, G. P., Shepherd, D., Nelson, T., Chandler, G. N., \& Zacharakis, A. (2003). Entrepreneurship Research in Emergence: Past Trends and Future Directions. Journal of Management, 29(3), 285-308. https://doi.org/10.1016/S0149-2063(03)00013-8

Chapple, W., Lockett, A., Siegel, D., \& Wright, M. (2005). Assessing the relative performance of U.K. University technology transfer offices: Parametric and non-parametric evidence. Research Policy, 34(3), 369-384. https://doi.org/10.1016/j.respol.2005.01.007

Charles, D., Kitagawa, F., \& Uyarra, E. (2014). Universities in crisis? New challenges and strategies in two English city-regions Cambridge Journal of Regions, Economy and Society. Cambridge Journal of Regions, Economy and Society, 7(2), 327-348. https://doi.org/10.1093/cjres/rst029

Clarysse, B., \& Bruneel, J., (2007). Nurturing and growing innovative start-ups: the role of policy as integrator. $R \& D$ Management 37(2), 139-149. https://doi.org/10.1111/j.1467-9310.2007.00463.x

Clarysse, B., \& Moray, N. (2004). A process study of entrepreneurial team formation: the case of a research-based spin-off. Journal of Business Venturing, 19, 59. https://doi.org/10.1016/S0883-9026(02)00113-1

Clarysse, B., Tartari, V., \& Salter, A. (2011). The impact of entrepreneurial capacity, experience and organizational support on academic entrepreneurship. Research Policy, 40, 1084-1093. https://doi.org/10.1016/j.respol.2011.05.010

Clarysse, B., Wright, M., Lockett, A., Mustar, P., \& Knockaert, M. (2007). Academic spinoffs, formal technology transfer and capital raising. Industrial and Corporate Change, 16(4), 609-640. 
https://doi.org/10.1093/icc/dtm019

Clarysse, B., Wright, M., Lockett, A., Van de Velde, E., \& Vohora, A. (2005). Spinning out new ventures: A typology of incubation strategies from European research institutions. Journal of Business Venturing, 20, 183-216. https://doi.org/10.1016/j.jbusvent.2003.12.004

Crespi, G. A., Geuna, A., \& Nesta, L. (2007). The mobility of university inventors in Europe. Journal of Technology Transfer, 32, 195-215. https://doi.org/10.1007/s10961-006-9012-0

Dosi, G., \& Orsenigo, L. (1998). Coordination and transformation: an overview of structures, behaviours and change in evolutionary environments. In: DOSI, G. et al (Eds.), Technical change and economic theory. London: Pinter.

Etzkowitz, H. (1998). The norms of entrepreneurial science: cognitive effects of the new university-industry linkages. Research Policy, 27, 823-833. https://doi.org/10.1016/S0048-7333(98)00093-6

Etzkowitz, H. (2003). Research groups as 'quasi-firms': the invention of the entrepreneurial university. Research Policy, 32, 109-121. https://doi.org/10.1016/S0048-7333(02)00009-4

Etzkowitz, H., \& Leydesdorff, L. (1998). The Triple Helix as a Model for Innovation Studies. Science \& Public Policy, 25(3), 195-203.

Etzkowitz, H., \& Leydesdorff, L. (1999). The Future Location of Research and Technology Transfer. Journal of Technology Transfer, 24, 111-123. https://doi.org/10.1023/A:1007807302841

Etzkowitz, H., \& Leydesdorff, L. (2000). The dynamics of innovation: from National Systems and "Mode 2" to a Triple Helix of university-industry-government relations. Research Policy, 29, 109-123. https://doi.org/10.1016/S0048-7333(99)00055-4

Fagerberg, J. (2006). Innovation: A guide to the literature. In: Fagerberg, J., Mowery, D., Nelson, R. (Eds.), The Oxford Handbook of Innovation. Oxford University Press, Oxford. https://doi.org/10.1093/oxfordhb/9780199286805.001.0001

Fagerberg, J., Srholec, M., \& Verspagen, B. (2010). The Role of Innovation in Development. Review of Economics and Institutions, 1(2), 1-29. https://doi.org/10.5202/rei.v1i2.2

Folha (2016). Ranking Universitário Folha de São Paulo. Retrieved 20.05 .2016 http://ruf.folha.uol.com.br/2016/ranking-de-universidades/

Fonseca, M. L. M (2014). Análise das incubadoras de empresas de base tecnológica como promotora do desenvolvimento regional brasileiro: uma abordagem teórica. XXIV Seminário Nacional de Parques Tecnológicos e Incubadoras de Empresas. Belém, Pará, Brasil, pp. 1-19.

Gervais, M. J., Marion, C., Dagenais, C., Chiocchio, F., \& Houlfort, N. (2016). Dealing with the complexity of evaluating knowledge transfer and innovation performance: Evidence from Chinese firms. Technological Forecasting \& Social Change, 73, 666-678.

Geuna, A., \& Muscio, A. (2009). The Governance of University Knowledge Transfer: A Critical Review of the Literature.

Gilsing, V., Bekkers, R., Bodas-Freitas, I. M., \& Van der Steen, M. (2011). Differences in technology transfer between science-based and development-based industries: Transfer mechanisms and barriers. Technovation, 31, 638-647. https://doi.org/10.1016/j.technovation.2011.06.009

Grimaldi, R., \& Grandi, A. (2005). Business incubators and new venture creation: An assessment of incubating models. Technovation, 25, 111-121. https://doi.org/10.1016/S0166-4972(03)00076-2

Guan, J. C., Mok, C. K., Yam, R. C. M., Chin, K. S. M., \& Pun, K. F. (2006). Technology transfer and innovation performance: Evidence from Chinese firms. Technological Forecasting \& Social Change, 73, 666-678. https://doi.org/10.1016/j.techfore.2005.05.009

Guerrero-Cano, M., Kirby, D., \& Urbano, D. (2006). A literature review on Entrepreneurial universities: An institutional approach. The 3rd Conference of Pre-communications to Congresses. Business Economic Department. Autonomous University of Barcelona. Barcelona, Spain.

IBGE. (2013). Produto Interno Bruto dos Municípios Brasileiros. Retrieved 23.08.2016 http://www.ibge.gov.br/home/estatistica/pesquisas/pesquisa_resultados.php?id_pesquisa=46 
Kirby, D. A., Guerrero, M., \& Urbano, D. (2011). Making Universities More Entrepreneurial: Development of a Model. Canadian Journal of Administrative Sciences/Revue Canadienne des Sciences de l'Administration, 28(3), 302-316.

Lee, Y. S. (1998). University-Industry Collaboration on Technology Transfer: Views from the Ivory Tower. Policy Studies Journal, 26(1), 69-84. https://doi.org/10.1111/j.1541-0072.1998.tb01925.x

Link, A. N., Siegel, D. S., \& Bozeman, B. (2007). An empirical analysis of the propensity of academics to engage in informal university technology transfer. Industrial and Corporate Change, 16(4), 1-15. https://doi.org/10.1093/icc/dtm020

Markman, G. D., Gianiodis, P. T., Phan, P. H., \& Balkin, D. B. (2005). Innovation speed: Transferring university technology to market. Research Policy, 34, 1058-1075. https://doi.org/10.1016/j.respol.2005.05.007

McMullen, J. S., \& Shepherd, D. A. (2006). Entrepreneurial action and the role of uncertainty in the theory of the entrepreneur. Academic Management Review, 31, 132-152. https://doi.org/10.5465/AMR.2006.19379628

Mello, J. M. C., \& Etzkowitz, H. (2008). New directions in Latin American university-industry-government interactions. International Journal of Technology Management and Sustainable Development, 7(3), 193-204. https://doi.org/10.1386/ijtm.7.3.193_1

Mian, S. A. (1997). Assessing and managing the university technology business incubator: An integrative framework. Journal of Business Venturing, 12(4), 251-285. https://doi.org/10.1016/S0883-9026(96)00063-8

Molas-Gallart, J., \& Castro-Martínez, E. (2008). Ambiguity and conflict in the development of 'Third Mission' indicators. Research Evaluation, 16(4), 321-330. https://doi.org/10.3152/095820207X263592

Mowery, D. C., \& Ziedonis, A. Z. (2014). Markets versus spillovers in outflows of university research. Research Policy, 44, 50-66. https://doi.org/10.1016/j.respol.2014.07.019

Muscio, A., Quaglione, D., \& Vallanti, G. (2014). University regulation and university-industry interaction: a performance analysis of Italian academic departments. Industrial and Corporate Change Advance, 1, 1-33.

Pausits, A. (2015). The Knowledge Society and Diversification of Higher Education: From the Social: Contract to the Mission of Universities. In Curaj, A. et al. (Eds.), The European Higher Education Area: Between Critical Reflections and Future Policies. Springer. https://doi.org/10.1007/978-3-319-20877-0_18

Pauwels, C., Clarysse, B., Wright, M., Van Hove, J. (2016). Understanding a new generation incubation model: The accelerator. Technovation, 50-51, 13-24. https://doi.org/10.1016/j.technovation.2015.09.003

Perkmann, M., Fini, R., Ross, J., Salter, A., Silvestri, C., \& Tartari, V. (2015). Accounting for universities' impact: Using augmented data to measure academic engagement and commercialization by academic scientists. Research Evaluation, 24(4), 380-391. https://doi.org/10.1093/reseval/rvv020

Phan, P. H., \& Siegel, D. S. (2006). The Effectiveness of University Technology Transfer. Foundations and Trends in Entrepreneurship, 2(2), 77-144. https://doi.org/10.1561/0300000006

Phan, P. H., Siegel, D. S., \& Wright, M. (2005). Science parks and incubators: observations, synthesis and future research. Journal of Business Venturing, 20, 165-182. https://doi.org/10.1016/j.jbusvent.2003.12.001

Piirainen, K. A., Andersen, P. D., \& Andersen, A. D. (2016). Foresight and the third mission of universities: The case for innovation system foresight. Foresight, 8(1), 1-34. https://doi.org/10.1108/fs-04-2014-0026

Power, D., \& Malmberg, A. (2008). The contribution of universities to innovation and economic development: In what sense a regional problem? Cambridge Journal of Regions, Economy and Society, 1, 233-245. https://doi.org/10.1093/cjres/rsn006

Ranga, M., \& Etzkowitz, H. (2013). Triple Helix systems: an analytical framework for innovation policy and practice in the Knowledge Society. Industry \& Higher Education, 27(3), 237-262. https://doi.org/10.5367/ihe.2013.0165

Ranga, M., Temel, S., Murat Ar, I., Yesilay, R. B., \& Sukan, F. V. (2016). Building Technology Transfer Capacity in Turkish Universities: a critical analysis. European Journal of Education, 51(1), 09-106.

Reddy, M., \& Zhao, I. (1990). International technology transfer: A review. Research Policy, 19(4), 285-307. https://doi.org/10.1016/0048-7333(90)90015-X

Roach, D. C., Ryman, J. A., \& Makani, J. (2016). Effectuation, innovation and performance in SMEs: An empirical study. European Journal of Innovation Management, 19(2), 214-238. https://doi.org/10.1108/EJIM-12-2014-0119 
Rogers, E. M., Takegami, S., \& Yin, J. (2001). Lessons learned about technology transfer. Technovation, 21, 253-261. https://doi.org/10.1016/S0166-4972(00)00039-0

Schaeffer, P. R., Dullius, A. C., Maldonado, R., \& Zawislak, P. A. (2015). Types of university-industry interaction: A new approach to bridge the gap between universities and industries. XVI Congresso Latino-Iberoamericano de Gestão Tecnologia. ALETC, Porto Alegre, Brasil.

Shane, S., \& Venkataraman, S. (2000). Thep romiseo f entrepreneurshaisp a field of reseanch. Academy of Managemenl Fleview, 25(1), 217-226.

Siegel, D. S., Veugelers, R., \& Wright, M. (2007). Technology transfer offices and commercialization of university intellectual property: Performance and policy implications. Oxford Review of Economic Policy, 23(4), 640-660. https://doi.org/10.1093/oxrep/grm036

Soetanto, D. P., \& Jack, S. L. (2013). Business incubators and the networks of technology based firms. Journal of Technology Transfer, 38(4), 432-453. https://doi.org/10.1007/s10961-011-9237-4

Sporn, B. (2001). Building Adaptive Universities: Emerging Organisational Forms Based on Experiences of European and US Universities. Tertiary Education and Management, 7(2), 121-134. https://doi.org/10.1080/13583883.2001.9967046

Stam, E., \& Bosma, N. (2015). Growing entrepreneurial economies: Entrepreneurship and regional development. In T. Baker \& F. Welter (Eds.), The Routledge Companion to Entrepreneurship (pp. 325-340).

Stam, E., Bosma, N., Van Witteloostuijn, A., Jong, J., Bogaert, S., Edwards, N., \& Jaspers, F. (2012). Ambitious Entrepreneurship. A Review of the Academic Literature and New Directions for Public Policy.

Taheri, M., \& Geenhuizen, M. (2016). Teams' boundary-spanning capacity at university: Performance of technology projects in commercialization. Technological Forecasting \& Social Change, in press. https://doi.org/10.1016/j.techfore.2016.06.003

Thorn, K., \& Soo, M. (2006). Latin American Universities and the Third Mission: Trend, Challenges and Policy Options. Policy Research Working Paper, 4002, The World Bank.

Trencher, G., Yarime, M., \& McCormi, K. B. (2013). Beyond the third mission: Exploring the emerging university function of co-creation for sustainability. Science and Public Policy, 1-29.

UKBI. (2007).What is Business Incubation? Retrieved 10.07.2016, from http://www.ukbi.co.uk

Warren, L., Kitagawa, F., \& Eatough, M. (2010). Developing the knowledge economy through university linkages an exploration of RDA strategies through case studies of two English regions. Entrepreneurship and innovation, 11(4), 293-306.

WEF. (2016). The Global Competitiveness Report 2015-2016. World Economic Forum Geneva. Retrieved 29.09.2016,

from http://www3.weforum.org/docs/gcr/2015-2016/Global_Competitiveness_Report_2015-2016.pdf

Wright, M., Birley, S., \& Mosey, S. (2004). Entrepreneurship and University Technology Transfer. Journal of Technology Transfer, 29, 235-246. https://doi.org/10.1023/B:JOTT.0000034121.02507.f3

York, J. G., \& Venkataraman, S. (2010). The entrepreneur-environment nexus: Uncertainty, innovation, and allocation. Journal of Business Venturing, 25, 449-463. https://doi.org/10.1016/j.jbusvent.2009.07.007

Zhao, L., \& Reisman, A. (1992). Toward Meta Research on Technology Transfer. IEEE Transactions on Engineering Management, 39(1), 13-21. https://doi.org/10.1109/17.119659

\section{Copyrights}

Copyright for this article is retained by the author(s), with first publication rights granted to the journal.

This is an open-access article distributed under the terms and conditions of the Creative Commons Attribution license (http://creativecommons.org/licenses/by/4.0/). 